Contaminant Uptake and Demography of the Loggerhead Shrike (Lanius ludovicianus) at the Lawrence Livermore National Laboratory, Site 300

M. G. van Hattem, G. Santolo

February 28, 2005 
This document was prepared as an account of work sponsored by an agency of the United States Government. Neither the United States Government nor the University of California nor any of their employees, makes any warranty, express or implied, or assumes any legal liability or responsibility for the accuracy, completeness, or usefulness of any information, apparatus, product, or process disclosed, or represents that its use would not infringe privately owned rights. Reference herein to any specific commercial product, process, or service by trade name, trademark, manufacturer, or otherwise, does not necessarily constitute or imply its endorsement, recommendation, or favoring by the United States Government or the University of California. The views and opinions of authors expressed herein do not necessarily state or reflect those of the United States Government or the University of California, and shall not be used for advertising or product endorsement purposes.

This work was performed under the auspices of the U.S. Department of Energy by University of California, Lawrence Livermore National Laboratory under Contract W-7405-Eng-48. 


\title{
Contaminant Uptake and Demography of the Loggerhead Shrike (Lanius ludovicianus) at the Lawrence Livermore National Laboratory, Site 300
}

\author{
Michael G. van Hattem ${ }^{1,3}$ and Gary M. Santolo ${ }^{2}$ \\ 1,3 Environmental Protection Department, Lawrence Livermore National Laboratory, PO Box 808, \\ L-627 Livermore, CA. 94551, USA \\ 2 CH2M HILL, Inc., 2458 Natomas Park Drive, Suite 600, Sacramento, California 95833, USA \\ ${ }_{3}^{3}$ Corresponding author (e-mail: vanhattem1@llnl.gov)
}

\begin{abstract}
Concentrations of eleven potential environmental contaminants (metals) in the blood and retrice feathers of fledged-Hatch Year and adult loggerhead shrikes (Lanius ludovicianus) were examined at Lawrence Livermore National Laboratory's Site 300 and a control site, in San Joaquin and Contra Costa Counties, California. The purpose of this pilot study was to determine, through non-lethal means, if loggerhead shrikes are exposed to metals at Site 300 and whether specific demographic variables (i.e., clutch size, fledging success, etc.) are affected. Loggerhead shrikes at Site 300 had higher blood concentrations of metals, especially birds on the west side of the site, when compared to control site birds. Metal concentrations in the feathers of control site birds tended to be higher than Site 300 shrikes. Blood concentrations of metals in loggerhead shrikes from both Site 300 and the control site were well below the Most Tolerant Dietary Level (MTDL) for domestic birds for all metals except selenium. Clutch size was similar to other populations but one deformed embryo was discovered in a failed egg. The results of this pilot study suggest further work is needed to understand possible synergistic effects related to other contaminants of concern found at Site 300 and overall population variability.
\end{abstract}

\section{INTRODUCTION}

Assessing ecosystem health adequately by means of biomonitoring requires the selection of indicator species that are representative for the considered ecosystem (Burger and Gochfeld, 1996). The loggerhead shrike (Lanius ludovicianus) inhabits ecotones, grasslands, and other open habitats and feeds on a variety of invertebrates and vertebrate prey (Yosef, 1996). Although a passerine, the raptorial habits of the loggerhead shrike lend it to occupy a unique position in the food chain as a top-level predator. Despite its wide distribution, the loggerhead shrike is one of the few North American passerines whose populations have declined continent wide in previous decades (Yosef, 1996).

In recent years, a critical need has developed to determine how exposure to contaminants in the environment affects both individuals and populations 
(Fair et al., 2003). However, it is not possible or desirable to collect whole animals and examine the element concentrations in their internal organs (Jansssens et al., 2001). Therefore, a non-destructive method of tissue sampling that allows repeated sampling of individuals is desirable.

Blood sampling did not show any noticeable negative effects in a study on great tits (Parus major), a small passerine bird (Lubjuhn et al. 1998). Santolo and Yamamoto (1999) found that blood selenium was a useful indicator of dietary selenium exposure in predatory birds and may be useful monitoring other metals as well. Yamamoto et al. (1998) observed a 1:1 relationship between dietary and peak blood selenium concentrations (dry weight basis) in birds receiving seleno-L-methionine in the diet and time to reach a plateau of selenium in the blood after about five weeks. Under a similar exposure regime in mallards, peak concentrations were achieved after a much longer period, 12 weeks, and a greater than 1:1 ratio between blood and diet selenium was reported (Heinz and Fitzgerald 1993). It appears that blood concentration, under conditions of chronic exposure, can facilitate estimation of the amount of selenium in the diet, as well as serve as an indicator of recent exposure.

Feathers may be a useful non-destructive method for measuring metal levels in birds (Burger 1996). Metals are deposited in feathers during their formation and are a record of circulating blood levels at the time of feather formation (Goede and de Bruin, 1984). The outermost tail feathers were collected from great tits at increasing distances from an industrial plant in Belgium to monitor metals pollution in the environment (Janssens et al. 2001). They found that both essential and nonessential elements accumulated into the feathers and the levels they found were consistent with air pollution results from their study site. They suggest that feathers can be used to monitor local exposure. However, birds are mobile and knowledge of where the bird was during feather growth may not be known. Furthermore, exogenous exposure may be of concern with feathers.

Site 300 is located in the Altamont Pass region of the Diablo Range about 80-km east of San Francisco, between the cities of Livermore and Tracy, California. Site 300 is approximately 2711-ha of open-rugged terrain, primarily composed of annual grasses, and to a lesser extent native grasslands, oak/juniper woodlands, freshwater wetlands, springs, and coastal sage scrub habitats. The control site, Los Vaqueros is located approximately 21-km north west of Site 300 between the cities of Livermore and Brentwood, California, and is comprised of similar habitat types in addition to a large drinking water reservoir.

Investigations into water and soil contamination at Site 300 have been ongoing since 1982; the Environmental Protection Agency placed Site 300 on the National Priorities List in 1990 (Carlsen, 1996). Loggerhead shrikes may be exposed to contaminants either directly or by consuming prey items that have been exposed. Contaminants at Site 300 include volatile organic compounds 
(VOCs), high-explosive compounds, metals, and radioisotopes (Carlsen, 1996). The purpose of this pilot study was to determine, through non-lethal means, if Loggerhead shrikes are exposed to metals at Site 300 and whether specific demographic variables (i.e., clutch size, fledging success, etc.) are affected.

\section{METHODS}

Both Site 300 and the control site were repeatedly surveyed during the onset of the 2004 breeding season (March - June) and breeding territories were delineated for Site 300 (Figure 1). Once a loggerhead shrike was encountered, all potential nest locations were investigated within a 1-km radius, some of which were previously known breeding locations. An active breeding territory was determined by the presence of foraging or sentinel adults, eggs/nestlings, or recently fledged young within the immediate vicinity of a nest tree. Fledglings were identified by plumage and begging behavior. Nestling loggerhead shrikes were individually marked with a unique U.S. Geological Survey aluminum legband, and repeated visits were done to band nestlings at the appropriate age ( $\sim 10$ days post-hatching). If failed eggs were discovered in the active nest or at any other nest within the territory, they were collected and individually marked for future analyses.

We captured loggerhead shrikes with a modified Potter's trap (MSB), using live mice (Mus musculus) or crickets as lures. The MSB was used in trapping attempts for birds considered capable of seeing a trap (up to about 100$\mathrm{m}$ from the road) by placing it onto the road shoulder from the vehicle and then observing the trap from a short distance away. Loggerhead shrikes were individually marked with a single aluminum leg band and 1 or 2 Darvic plastic color leg bands, overlapped and fused with a portable soldering iron. Loggerhead shrikes were aged (HY=Hatch Year, SY=Second Year, ASY=After Second Year) and sexed according to Pyle (1997), and basic morphometrics were recorded, including weight and molt.

We used a heparanized 1-mL insulin syringe to draw up to $0.3-\mathrm{mL}$ of blood from the jugular vein. Blood was stored in 1.5-mL Eppendorf Flex-tubes (Brinkmann Instruments, Inc., Westbury, New York, USA) and frozen below $-80^{\circ} \mathrm{C}$ for metals analysis. An outer-tail feather (r6) was pulled and stored for analyses along with any body feathers lost during processing. All measurements and blood sampling were done at the capture site, where shrikes were released immediately after processing was complete. Territory wide re-sight surveys were conducted after banding in the three consecutive months following initial banding to determine if study birds were resident. Survey routes were driven in a similar approach each month and birds were re-sighted using a Kowa ${ }^{\mathrm{TM}}$ spotting scope (TSN 20-60x $80 \mathrm{~mm}$ ).

In the laboratory, feathers were rinsed in doubly distilled deionized water prior to analysis. Blood samples were analyzed with no pretreatment. All 
samples were digested at $80^{\circ} \mathrm{C}$ for 6 hours in $2 \%$ ultra-pure nitric acid. All digests were analyzed by Inductively Coupled Plasma Atomic Emission (ICPAES) for $\mathrm{Be}, \mathrm{U}, \mathrm{Pb}, \mathrm{Mn}, \mathrm{Se}, \mathrm{Si}, \mathrm{V}, \mathrm{Al}, \mathrm{Cd}, \mathrm{Cr}$ and $\mathrm{Fe}$. Measured concentrations were multiplied by the final sample mass for digestion to calculate $\mathrm{mg} / \mathrm{kg}$ concentrations.

\section{Statistical Analyses}

Comparisons of blood and feather results among study areas (i.e., Site 300 (east side and west side) and the control site (Los Vaqueros) were made using 1way analysis of variance (ANOVA) and the Scheffé $\mathrm{F}$ test for multiple means comparisons (site differences; SAS Institute, 1998; Zar, 1974), and significance was inferred at the $P<0.05$ level. Feather and blood metal concentrations were $\log$-transformed due to positive skewing of the data. Statistical comparison of means was restricted to samples with $n \geq 3$. Log transformed data are reported as geometric means. All blood and feather results are on a dry weight basis.

\section{RESULTS}

\section{Natural History and Demography}

Loggerhead shrikes are relatively ubiquitous at Site 300 and territories are predictably situated near suitable nest trees in open habitat. Twenty-one active territories were identified at Site 300 during the course of spring and summer surveys (Figure 1). Thirty-five nestlings were banded at Site 300 and five were banded at the control site. Of the 21 Site 300 territories, 18 nests produced 79 young. Average brood size was 4.38 (1.5 SD, n=18, 6 failed eggs collected) for all breeding territories, and average clutch size was 4.88 (1.45 SD, n=9, 5 failed eggs collected) for territories where nestlings were not independent of the nest tree and the brood could be quantified. Site 300 loggerhead shrikes nested mostly in juniper (Juniperus californicus) $(\mathrm{n}=10)$, and to a lesser extent oaks (Quercus spp.) $(\mathrm{n}=3)$, mulefat (Baccharis salicifolia) $(\mathrm{n}=3)$, oleander (Nerium oleander) $(\mathrm{n}=1)$, and at least one nest appears to be associated with Russian thistle (Salsola kali) (Yosef, 1996).

We captured, color banded, and collected tissue samples from 36 loggerhead shrikes, ( $n=25$ from Site 300, $n=11$ from the control site). The age structure of sampled shrikes was 18-HY, 16-SY, and 2-ASY, but sex was not determinable on any shrike because of age (HY) or lack of brood patch (i.e., seasonality). The total number of loggerhead shrike re-sights during follow-up surveys was 18, 5-HY, 10-SY, and 3-ASY. Of the re-sighted loggerhead shrikes, $28 \%$ were HY and $72 \%$ were SY and ASY (i.e., adults), and the number of resighted birds increased from $11 \%(n=2)$ in August to 39\% $(n=7)$ in November. 


\section{Contaminant Analysis}

Neither beryllium nor uranium was detected above minimum detection limits (mdl) and lead analysis was plagued by wavelength interference so no quantitative data was produced.

\section{Aluminum}

The geometric mean aluminum concentration in blood samples from loggerhead shrikes from Site 300 was elevated in west side shrikes $(p \leq 0.06)$ and east side shrikes $(p \leq 0.06)$ compared to the control site (Figure 2$)$. The range of aluminum in shrike blood from Site 300 was 5.5 to $149 \mathrm{mg} \mathrm{Al} / \mathrm{kg}$ below the Most Tolerant Dietary Level (MTDL) of $200 \mathrm{mg} \mathrm{Al} / \mathrm{kg}$ (NRC 1980).

The geometric mean aluminum concentration in shrike feathers from birds from Site 300 was similar in east side shrikes $(p \leq 0.63)$ and slightly lower in shrikes captured on the west side $(p \leq 0.03)$ compared to concentrations in birds from the control site. Mean concentrations of aluminum in feathers from great tits ranged from 27.7 to $58.3 \mathrm{mg} \mathrm{Al} / \mathrm{kg}$ (Janssens et al. 2001) many times lower than the levels found in most feathers from Site 300 and control shrikes.

\section{Cadmium}

Cadmium was not detected in blood samples from loggerhead shrikes from either study site.

Cadmium was only detected in two feather samples from Site 300 (Figure 3). The geometric mean cadmium concentration in shrike feathers from birds from Los Vaqueros was below the concentration of $4.55 \mathrm{mg} \mathrm{Cd} / \mathrm{kg}$ found in great tits sampled $2.5 \mathrm{~km}$ from a pollution source (Janssens et al. 2001).

\section{Chromium}

The geometric mean chromium concentration in blood samples from shrikes from Site 300 was significantly higher in east side shrikes $(p<0.01)$ compared to shrikes from the control site but west side shrikes had an intermediate geometric mean concentration (Figure 4). The range of chromium in shrike blood from Site 300 was 0.3 to $8.3 \mathrm{mg} \mathrm{Cr} / \mathrm{kg}$ below the MTDL of 1000 $\mathrm{mg} \mathrm{Cr} / \mathrm{kg}$ (NRC 1980).

The geometric mean chromium concentration in shrike feathers from birds from Site 300 was significantly lower (e.g., east side shrikes, $p<0.01$; west side, $p$ $<0.01$ ) compared to geometric mean concentration in shrikes from the control site. Mean concentrations of chromium in feathers from great tits ranged from 1.33 to $2.17 \mathrm{mg} \mathrm{Cr} / \mathrm{kg}$ (Janssens et al. 2001) lower than the geometric mean concentrations found in feathers from Site 300 and control loggerhead shrikes.

\section{Iron}

The geometric mean iron concentration in blood samples from loggerhead shrikes was similar among the three sites (Figure 5). The range of iron in loggerhead shrike blood from Site 300 was 28.1 to $489 \mathrm{mg} \mathrm{Fe} / \mathrm{kg}$, below the MTDL of $1000 \mathrm{mg} \mathrm{Fe} / \mathrm{kg}$ (NRC 1980). 
The geometric mean iron concentration in loggerhead shrike feathers from Site 300 was similar in west side shrikes $(p \leq 0.16)$ and significantly lower in shrikes captured on the east side $(p \leq 0.012)$ compared to concentrations in birds from the control site. Mean concentrations of iron in feathers from great tits ranged from 76.7 to $108 \mathrm{mg} \mathrm{Fe} / \mathrm{kg}$ (Janssens et al. 2001) many times lower than the levels found in most feathers from Site 300 and control loggerhead shrikes.

\section{Manganese}

The geometric mean manganese concentration in blood samples from loggerhead shrikes from Site 300 was significantly elevated in shrikes (e.g., east side shrikes, $p<0.01$; west side, $p<0.01$ ) compared to the Los Vaqueros site shrikes (Figure 6). The range of manganese in loggerhead shrike blood from Site 300 was 0.6 to $2.7 \mathrm{mg} \mathrm{Mn} / \mathrm{kg}$, many times below the MTDL of $2000 \mathrm{mg} \mathrm{Mn} / \mathrm{kg}$ (NRC 1980).

The geometric mean manganese concentration in feather samples from shrikes from Site 300 was significantly lower in shrikes (e.g., east side shrikes, $p<$ 0.01 ; west side, $p<0.01$ ) compared to the control site shrikes. Mean concentrations of manganese in feathers from great tits ranged from 17.4 to 43.8 $\mathrm{mg} \mathrm{Mn} / \mathrm{kg}$ (Janssens et al. 2001). The geometric mean concentration found in feathers from Site 300 were slightly above the low end of the range for great tits and the geometric mean concentrations in control site loggerhead shrike feathers were above the high end of the range in great tits.

\section{Selenium}

The geometric mean selenium concentration in blood samples from loggerhead shrikes from Site 300 was significantly elevated in east side shrikes ( $p$ $\leq 0.01$ ) compared to shrikes from the control site and west side shrikes had an intermediate geometric mean concentration (Figure 7). The range of selenium in loggerhead shrike blood from Site 300 was 0.1 to $32.5 \mathrm{mg} \mathrm{Se} / \mathrm{kg}$. The geometric mean selenium concentration in east side shrikes was slightly above the MTDL of $2 \mathrm{mg} \mathrm{Se} / \mathrm{kg}$ (NRC 1980). Geometric mean blood selenium concentrations were similar to those reported by Santolo and Yamamoto (1999) in loggerhead shrikes from the San Francisco Bay area (3.1 mg Se $/ \mathrm{kg}$ ) and the Sacramento Valley (3.6 $\mathrm{mg} \mathrm{Se} / \mathrm{kg}$ ) and lower than concentrations found in loggerhead shrikes from the Central Valley $(8.5 \mathrm{mg}$ Se $/ \mathrm{kg}$; excluding birds from Kesterson Reservoir, a known high selenium area), and loggerhead shrikes from Kesterson Reservoir (13 mg Se/kg).

The geometric mean selenium concentration in loggerhead shrike feathers from birds from Site 300 was significantly lower in east side $(p<0.01)$ and west side $(p \leq 0.02)$ shrikes compared to concentrations in birds from the control site. Mean concentrations of selenium in feathers from great tits ranged from 0.83 to $22.4 \mathrm{mg} \mathrm{Se} / \mathrm{kg}$ (Janssens et al. 2001). Feathers from Site 300 and the control site loggerhead shrikes fell within this range. 


\section{Silicon}

The geometric mean silicon concentration in blood samples from shrikes from Site 300 was elevated in west side shrikes $(p<0.01)$ and east side shrikes $(p$ $<0.01$ ) compared to the control site (Figure 8 ). The range of silicon in loggerhead shrike blood from Site 300 was 1.6 to $66.8 \mathrm{mg} \mathrm{Si} / \mathrm{kg}$. No data was found on the MTDL for silicon (NRC 1980).

The geometric mean silicon concentration in loggerhead shrike feathers was similar in shrikes from all three sites. No data was found on silicon in feathers of birds from other studies.

\section{Vanadium}

Vanadium was not detected in blood samples from loggerhead shrikes from any of the study sites.

The geometric mean vanadium concentration in loggerhead shrike feathers from birds from the east side of Site 300 was similar to concentrations in birds from the control site (Figure 9). Information on vanadium in feathers of birds from other studies was not found.

\section{DISCUSSION}

Loggerhead shrikes are found from the most developed areas of Site 300 (e.g., General Services Area) to the most remote, least anthropogenic influenced corners of the study area. Loggerhead shrikes are also relatively abundant at Los Vaqueros and showed the same general distribution trend with suitable nest trees determining the presence or absence of active breeding territories. Loggerhead shrikes typically nest at both sites in trees or shrubs with dense foliage although some exceptions were found (i.e., oleander) and may be more indicative of the lack of dense higher quality nest trees or shrubs. Junipers appear to be a critically important nesting feature at Site 300. Loggerhead shrikes at Site 300 showed strong site fidelity throughout the duration of this pilot study and appeared to be year round residents based on re-sight data, which is consistent with other populations in California. Productivity in terms of clutch size from known nests at Site 300 was less $(4.88 \pm 1.45 \mathrm{SD}, \mathrm{n}=9)$ than museum records $(5.4 \pm 1.1 \mathrm{SD}, \mathrm{n}=1,056$, Western Foundation of Vertebrate Zoology). In addition, 8 failed eggs were collected from Site 300 loggerhead shrike nests. In four of the eggs, embryos were analyzed, two of which were old enough to look for deformities. Of the two embryos analyzed, one showed severe deformities. Further monitoring is needed to understand clutch size differences and egg failure at Site 300. Similarly, nest success and clutch and brood sizes were not determined at the control site, nor were failed eggs collected so we were not able to compare these demographic variables with Site 300 . 
Blood concentrations of metals in loggerhead shrikes from both Site 300 and the control site were well below the MTDL for domestic birds for all metals except selenium. The geometric mean selenium concentration in birds from the east side of Site 300 was $2.4 \mathrm{mg} \mathrm{Se} / \mathrm{kg}$, slightly above the $2.0 \mathrm{mg} \mathrm{Se} / \mathrm{kg}$ MTDL (NRC 1980). As a general interpretive guideline, blood selenium concentrations exceeding about $4 \mathrm{mg} \mathrm{Se} / \mathrm{kg}$ warrant further study (USDI, 1998). Half of the 24 shrikes sampled in Site 300 exceeded the MTDL for selenium and six of the samples exceed the National Irrigation Water Quality Program guideline (USDI 1998). However, only one shrike showed a blood selenium concentration above the concentrations found in shrikes from Kesterson. American kestrels (Falco sparverius) fed 0, 6, and $12 \mathrm{mg}$ Se/ $\mathrm{kg}$ dietary selenium reflected the dietary selenium levels in their blood. Furthermore, they showed a negative relationship $\left(r^{2}=0.496\right)$ between blood selenium concentration and lean mass, suggesting that elevated selenium levels have a negative effect on body condition of birds (Yamamoto and Santolo, 2000).

Metal concentrations in feathers collected during this study are difficult to interpret simply because they represent blood concentrations when feathers were grown in. The short duration of this study lends itself to relying more heavily on the concentrations found in the blood, which depicts current concentrations and excludes exogenous variables. Further investigation of loggerhead shrikes at Site 300 and at the control site may improve our understanding of how feather concentrations relate to loggerhead shrike demography. Loggerhead shrikes at Site 300 appear to be in reasonable health, particularly based on blood metal concentrations determined by this pilot study. However, further investigation is needed to understand possible synergistic effects relative to other contaminants (i.e., VOCs, tritium) known to occur at Site 300 within loggerhead shrike breeding territories.

\section{ACKNOWLEDGMENTS}

This work was performed under the auspices of the U. S. Department of Energy (DOE) by the University of California, Lawrence Livermore National Laboratory (LLNL) under Contract No. W-7405-Eng-48. The project (04-ERD-091) was funded by the Laboratory Directed Research and Development Program at LLNL. We thank G. Bench for analytical support and guidance, J. Garrison for assistance with fieldwork and early writing revisions, T. Kato for support and guidance throughout the project, M. Shea with fieldwork at Los Vaqueros, and J. Lane for supporting wildlife research and monitoring at Site 300. This work was conducted under Institutional Animal Care and Use Committee Protocol \#178, California Department of Fish and Game Scientific Collectors Permit \#002814 and associated Memorandum of Understanding, and Federal Bird Banding Permit \#23916. 


\section{LITERATURE CITED}

Burger, J., C.T. Nisbet, and M. Gochfeld. 1994. Heavy Metal and Selenium Levels in Feathers of Known-Aged Common Terns (Sterna hirundo). Environmental Contamination and Toxicology 26, 351-355.

Burger, J., and M. Gochfield. 1996. Ecological and Human health risks assessment: a comparison. In: Di Guilio RT, Monosson E (eds) Interconnections between human and ecosystem health. Chapman and Hall, London, pp 127-148.

Carlsen, T. M. 1996. Ecological risks for fossorial vertebrates from volatile organic compounds in soil. Risk Analysis 16:211-219.

Fair, J. M., O. B. Myers, and R. E. Ricklefs. 2003. Immune and growth response of western bluebirds and ash-throated flycatchers to soil contaminants. Ecological Applications 13(6):1817-1829.

Goede, A. A., and de Bruin, M. 1984. The use of birds feather parts as a monitor for metal pollution. Environmental Pollution Service Bulletin 8:281-298.

Heinz, G. H., and M. A. Fitzgerald. 1993. Overwinter survival of mallards fed selenium. Archives of Environmental Contaminants and Toxicology 25:90-94.

Janssens, E., T. Dauwe, L. Bervoets, and M. Eens. 2001. Heavy metals and selenium in feathers of great tits (Parus major) along a pollution gradient. Environmental Toxicology and Chemistry 20:2815-2820.

Lubjuhn, T., J. Brün, W. Winkel, S. Muth. 1998. Effects of blood sampling in great tits. Journal of Field Ornithology 69:595-602.

National Research Council. 1980. Mineral Tolerance of Domestic Animals, National Academy of Domestic Animals, National Academy of Science, Washington DC.

Pyle, P. 1997. Identification guide to North American birds. Part I. Slate Creek Books, Bolinas, CA. (Library of Congress No. 97-69065).

Santolo, G. M., and J. T. Yamamoto. 1999. Selenium in blood of predatory birds from Kesterson Reservoir and other areas in California. Journal of Wildlife Management 63:1273-1281. 
SAS Institute. 1996. StatView reference. Release 5.0. SAS Institute, Cary, North Carolina, USA.

U.S. Department of the Interior (USDI). 1998. Guidelines for Interpretation of the Biological Effects of Selected Constituents in Biota, Water, and Sediment. USDI (Bureau of Reclamation, U.S. Fish and Wildlife Service, U.S. Geological Survey, Bureau of Indian Affairs), National Irrigation Water Quality Program Information Report No. 3. Bureau of Reclamation, Denver.

Yamamoto, J. T., G. M. Santolo, and B. W. Wilson. 1998. Selenium accumulation in captive American kestrels (Falco sparverius) fed selenomethionine and naturally incorporated selenium. Environmental Toxicology and Chemistry 17:2494-2497.

Yamamoto, J. T. and G. M. Santolo. 2000. Body condition effects in American kestrels fed selenomethionine. Journal of Wildlife Diseases 36:646-652.

Yosef, R. 1996. Loggerhead Shrike in The Birds of North America. No. 231.

Zar, J. H. 1974. Biostatistical analysis. Prentice-Hall, Engelwood Cliffs, New Jersey, USA. 


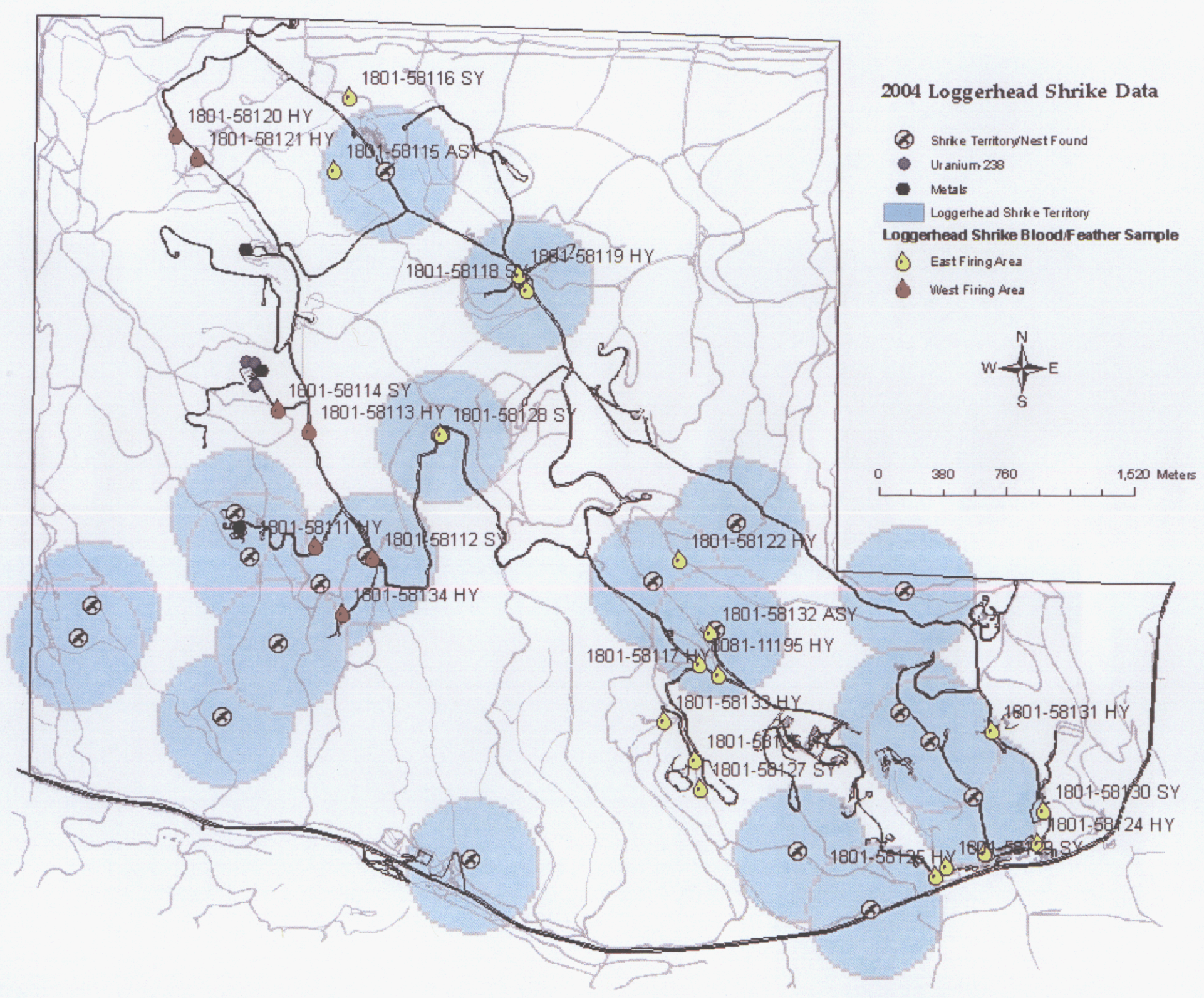

Figure 1. Loggerhead shrike territories/nests, known metal contamination areas, and the band number and age of each shrike at the capture point (HY= Hatch Year, SY= Second Year, ASY=After Second Year). 


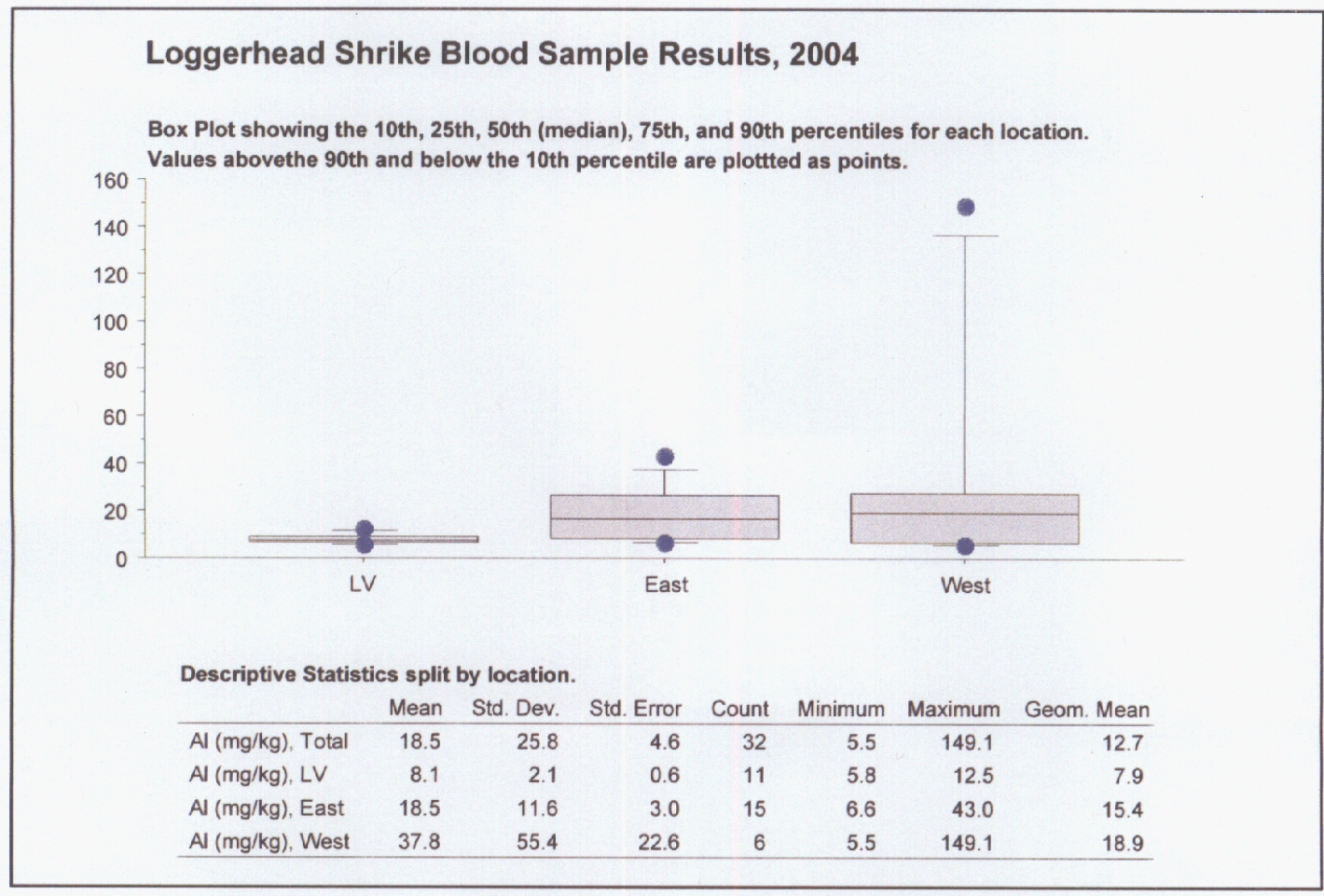

\section{Loggerhead Shrike Feather Sample Results, 2004}

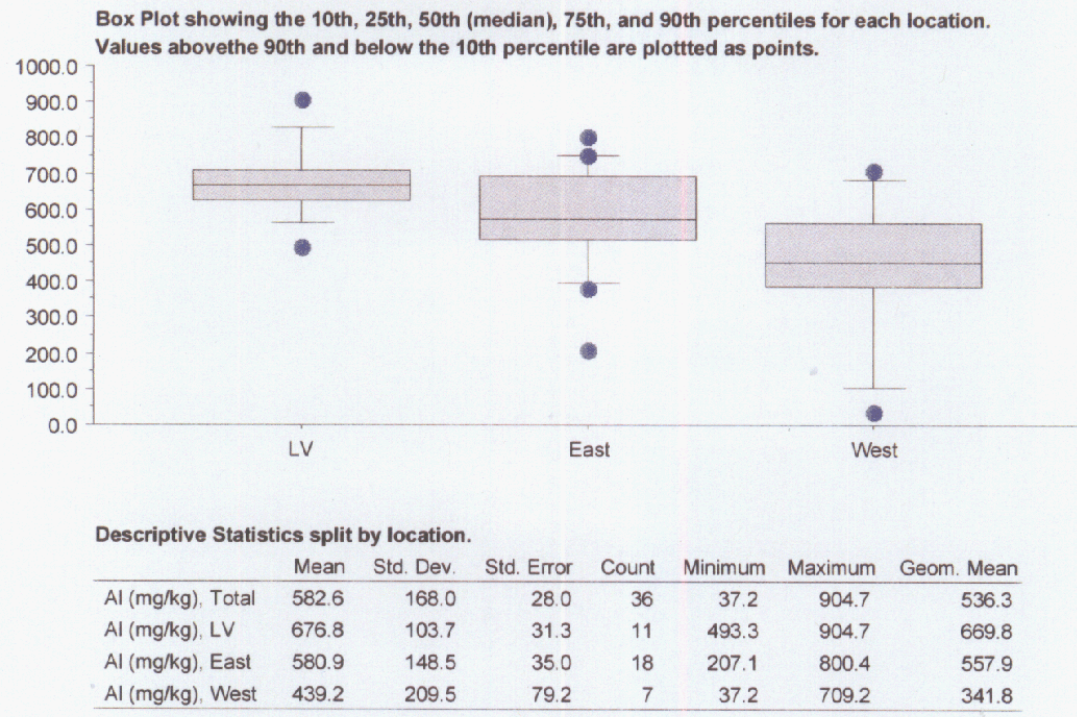

Figure 2. Comparison of Aluminum concentrations from all loggerhead shrike blood (upper) and feather (lower) samples at Site 300, the control site (LV), and between the east and west areas of Site 300 . Blood, the most accurate for realtime exposure, showed that west area shrikes contained the highest concentration of aluminum, but below Most Tolerant Dietary Level (MTDL). 
Loggerhead Shrike Feather Sample Results, 2004

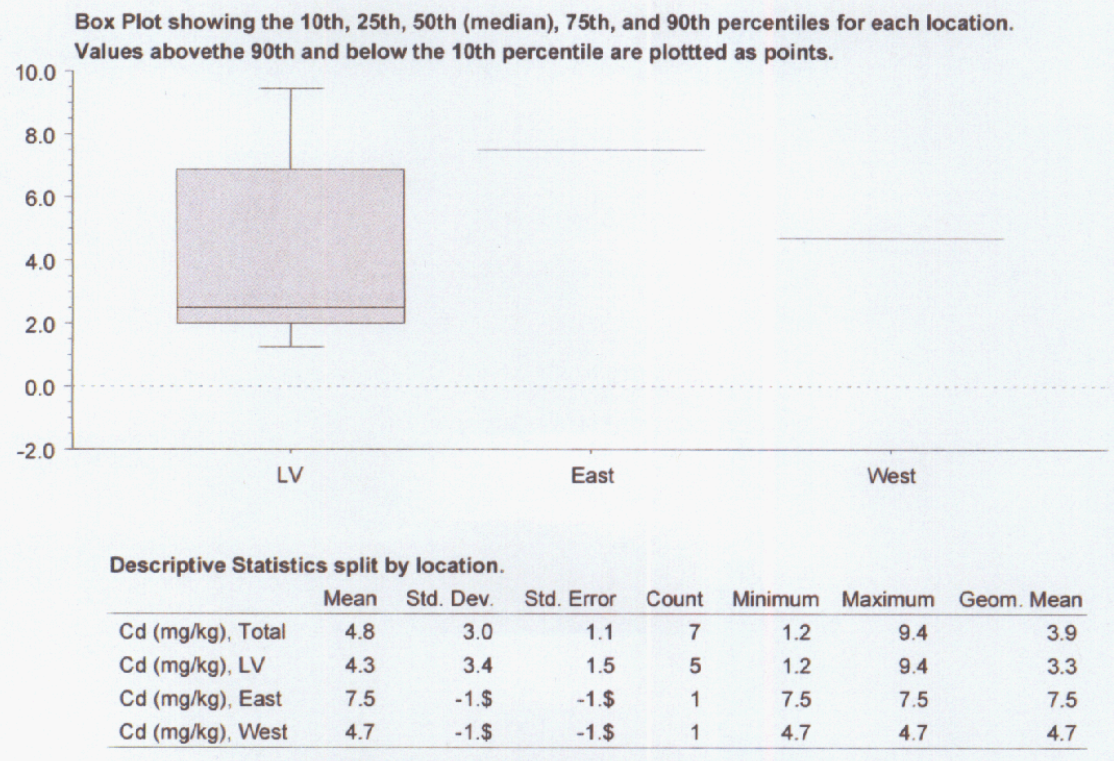

-1\$: Too few samples to calculate Standard Deviation or Standard Error

Figure 3. Cadmium was not detected in the blood of any of the loggerhead shrikes at either site and in only two feather samples from Site 300. 


\section{Loggerhead Shrike Blood Sample Results, 2004}

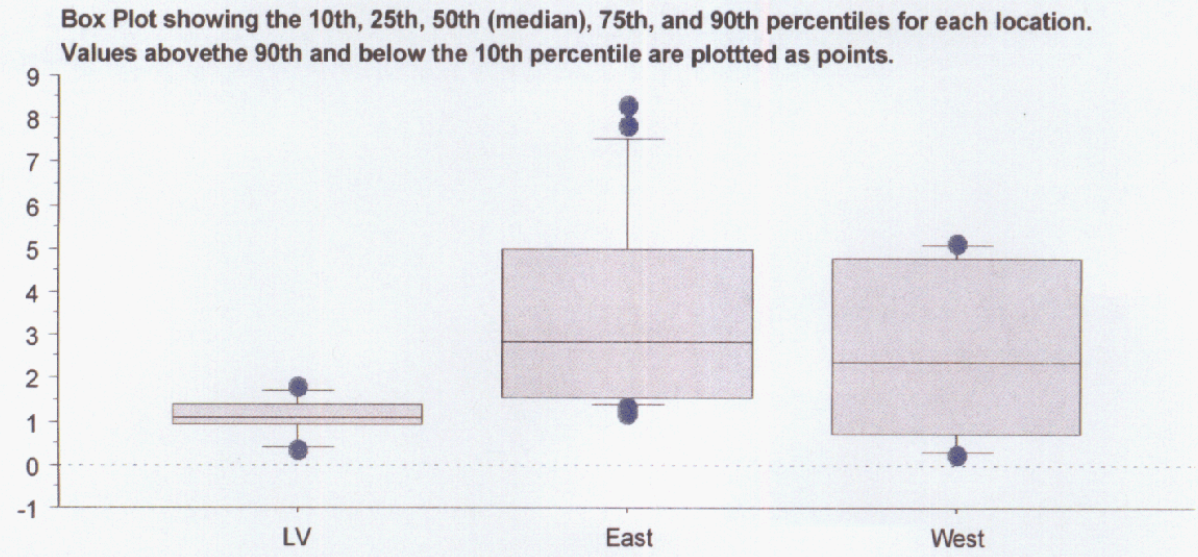

Descriptive Statistics split by location.

\begin{tabular}{lrrrrrrr} 
& Mean & Std. Dev. & Std. Error & Count & Minimum & Maximum & Geom. Mean \\
\hline $\mathrm{Cr}(\mathrm{mg} / \mathrm{kg})$, Total & 2.6 & 2.1 & 0.4 & 35 & 0.3 & 8.3 & 1.9 \\
$\mathrm{Cr}(\mathrm{mg} / \mathrm{kg})$, LV & 1.1 & 0.5 & 0.1 & 11 & 0.3 & 1.8 & 1.0 \\
$\mathrm{Cr}(\mathrm{mg} / \mathrm{kg})$, East & 3.6 & 2.2 & 0.5 & 18 & 1.2 & 8.3 & 3.0 \\
$\mathrm{Cr}(\mathrm{mg} / \mathrm{kg})$, West & 2.6 & 2.1 & 0.9 & 6 & 0.3 & 5.1 & 1.7 \\
\hline
\end{tabular}

\section{Loggerhead Shrike Feather Sample Results, 2004}

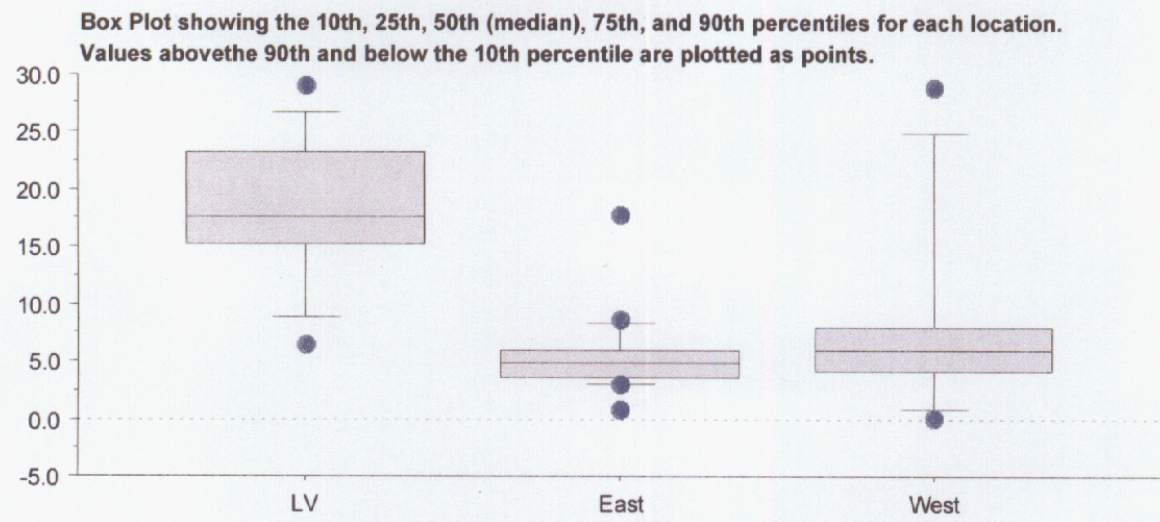

\begin{tabular}{|c|c|c|c|c|c|c|c|}
\hline & Mean & Std. Dev. & Std. Error & Count & Minimum & Maximum & Geom. Mean \\
\hline $\mathrm{Cr}(\mathrm{mg} / \mathrm{kg})$, Total & 9.9 & 8.1 & 1.4 & 35 & 0.1 & 29.2 & 6.5 \\
\hline $\mathrm{Cr}(\mathrm{mg} / \mathrm{kg}), \mathrm{LV}$ & 17.8 & 6.6 & 2.0 & 11 & 6.5 & 29.2 & 16.5 \\
\hline $\mathrm{Cr}(\mathrm{mg} / \mathrm{kg})$, East & 5.4 & 3.6 & 0.9 & 17 & 0.8 & 17.7 & 4.6 \\
\hline $\mathrm{Cr}(\mathrm{mg} / \mathrm{kg})$, West & 8.3 & 9.5 & 3.6 & 7 & 0.1 & 28.9 & 36 \\
\hline
\end{tabular}

Figure 4. Blood chromium levels were significantly higher $(\mathrm{p}<0.01)$ in east area shrikes compared to control shrikes, west area shrikes were intermediate, however all chromium levels were below Most Tolerant Dietary Level (MTDL). Chromium levels in feathers were significantly lower $(\mathrm{p}<0.01)$ at Site 300 compared to the control site feathers. 


\section{Loggerhead Shrike Blood Sample Results, 2004}

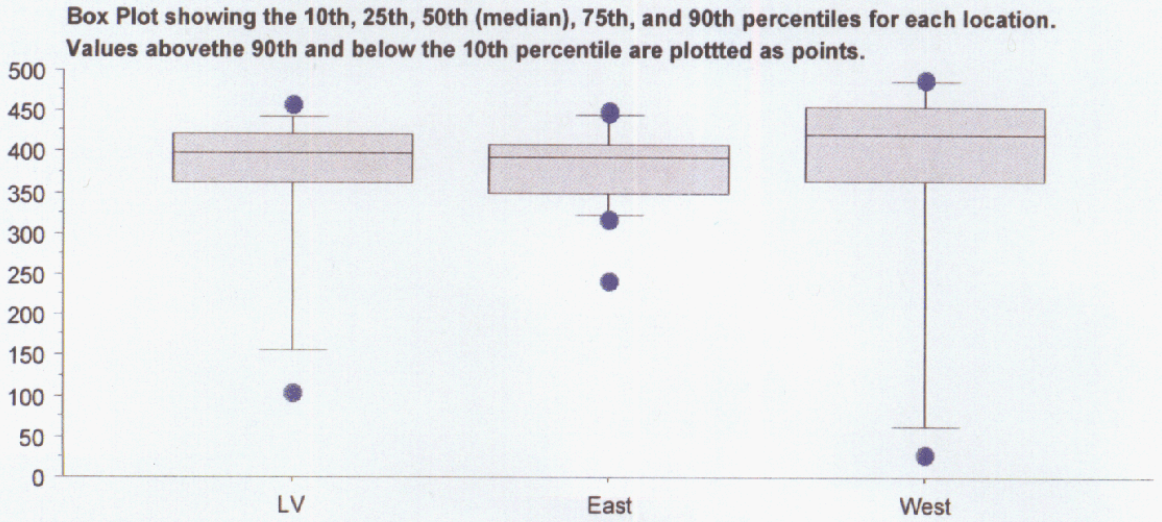

Descriptive Statistics split by location.

\begin{tabular}{lrrrrrrr} 
& Mean & Std. Dev. & Std. Error & Count & Minimum & Maximum & Geom. Mean \\
\hline $\mathrm{Fe}(\mathrm{mg} / \mathrm{kg})$, Total & 370.3 & 96.1 & 16.2 & 35 & 28.1 & 489.1 & 342.6 \\
$\mathrm{Fe}(\mathrm{mg} / \mathrm{kg})$, LV & 359.5 & 109.6 & 33.0 & 11 & 103.7 & 458.6 & 334.9 \\
$\mathrm{Fe}(\mathrm{mg} / \mathrm{kg})$, East & 379.0 & 52.5 & 12.4 & 18 & 242.7 & 450.2 & 375.2 \\
$\mathrm{Fe}(\mathrm{mg} / \mathrm{kg})$, West & 363.6 & 169.9 & 69.4 & 6 & 28.1 & 489.1 & 272.0 \\
\hline
\end{tabular}

\section{Loggerhead Shrike Feather Sample Results, 2004}

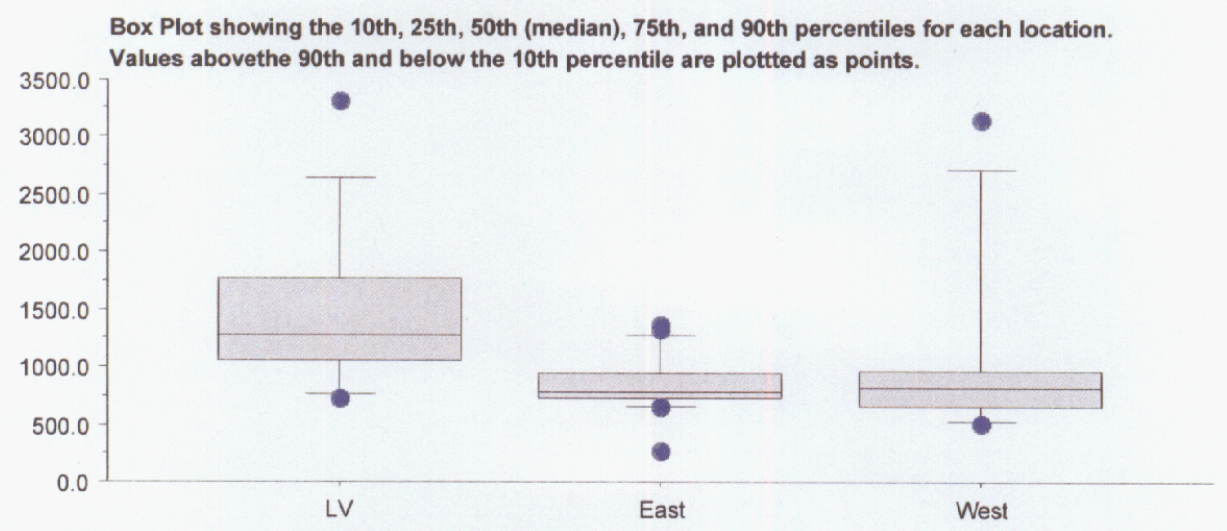

Descriptive Statistics split by location.

\begin{tabular}{lrrrrrrr} 
& Mean & Std. Dev. & Std. Error & Count & Minimum & Maximum & Geom. Mean \\
\hline $\mathrm{Fe}(\mathrm{mg} / \mathrm{kg})$, Total & 1102.8 & 645.2 & 107.5 & 36 & 278.7 & 3319.4 & 976.6 \\
$\mathrm{Fe}(\mathrm{mg} / \mathrm{kg})$, LV & 1509.6 & 742.0 & 223.7 & 11 & 721.8 & 3319.4 & 1374.4 \\
$\mathrm{Fe}(\mathrm{mg} / \mathrm{kg})$, East & 853.5 & 253.1 & 59.7 & 18 & 278.7 & 1371.0 & 813.0 \\
$\mathrm{Fe}(\mathrm{mg} / \mathrm{kg})$, West & 1104.5 & 916.1 & 346.3 & 7 & 504.5 & 3146.2 & 914.8 \\
\hline
\end{tabular}

Figure 5. Iron concentration in loggerhead shrike blood was similar among all three sites and below Most Tolerant Dietary Level (MTDL). East area shrikes had significantly lower feather iron levels $(P \leq 0.012)$ than west area and control shrikes. 


\section{Loggerhead Shrike Blood Sample Results, 2004}

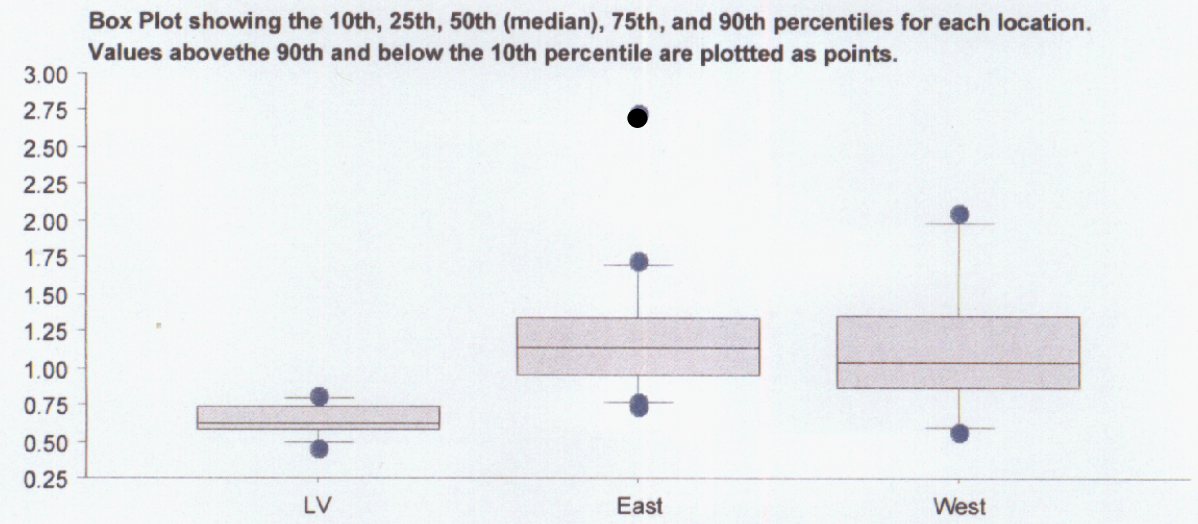

Descriptive Statistics split by location.

\begin{tabular}{lrrrrrrr} 
& Mean & Std. Dev. & Std. Error & Count & Minimum & Maximum & Geom. Mean \\
\hline Mn (mg/kg), Total & 1.0 & 0.5 & 0.1 & 35 & 0.5 & 2.7 & 0.9 \\
Mn (mg/kg), LV & 0.6 & 0.1 & $3.3 E-2$ & 11 & 0.5 & 0.8 & 0.6 \\
Mn (mg/kg), East & 1.2 & 0.5 & 0.1 & 18 & 0.7 & 2.7 & 1.2 \\
Mn (mg/kg), West & 1.1 & 0.5 & 0.2 & 6 & 0.6 & 2.0 & 1.1 \\
\hline
\end{tabular}

\section{Loggerhead Shrike Feather Sample Results, 2004}

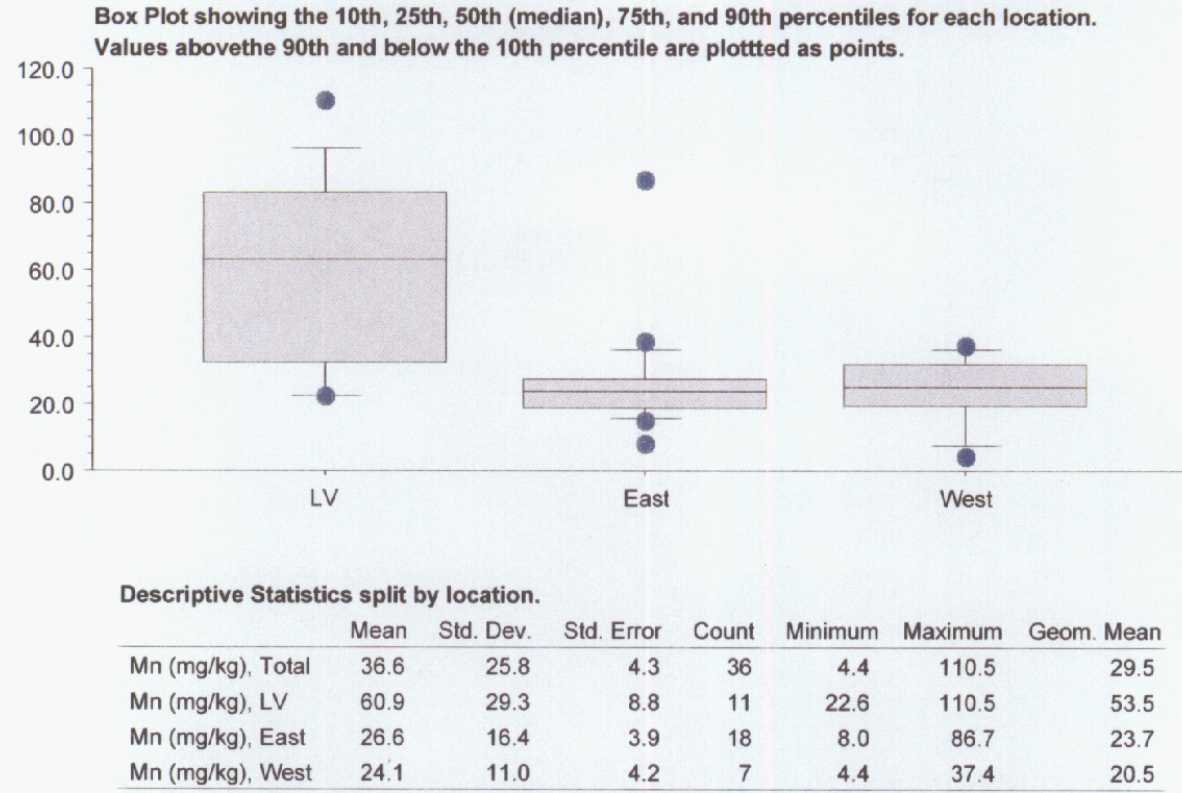

Figure 6. Manganese blood concentrations in Site 300 shrikes were significantly higher $(\mathrm{p}<0.01)$ than control site birds, but many times below Most Tolerant Dietary Level (MTDL). Manganese concentrations in feathers were significantly lower $(\mathrm{p}<0.01)$ in Site 300 loggerhead shrikes than control birds. 


\section{Loggerhead Shrike Blood Sample Results, 2004}

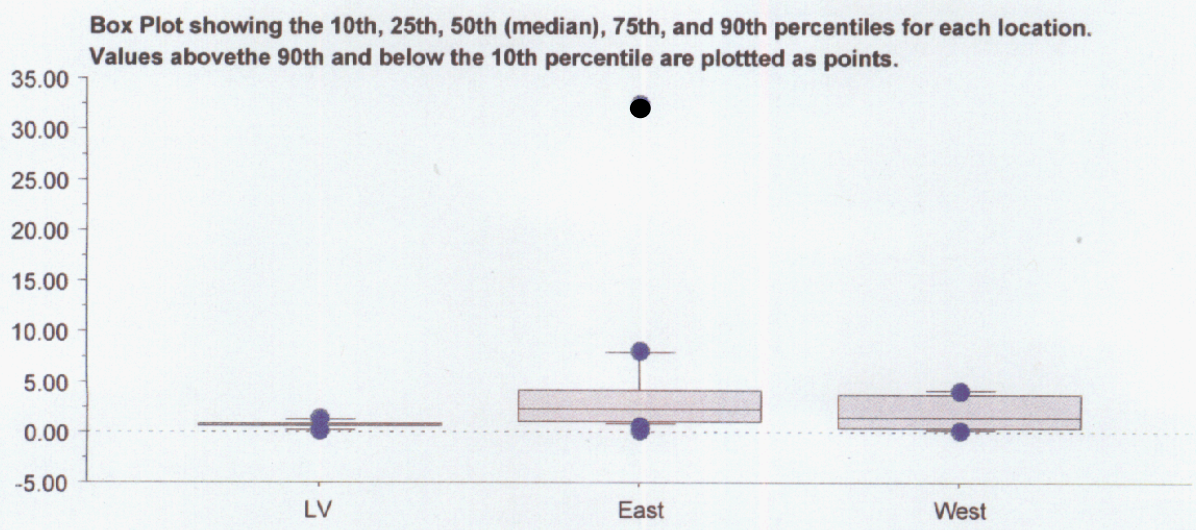

Descriptive Statistics split by location.

\begin{tabular}{lrrrrrrr} 
& Mean & Std. Dev. & Std. Error & Count & Minimum & Maximum & Geom. Mean \\
\hline Se $(\mathrm{mg} / \mathrm{kg})$, Total & 2.9 & 5.5 & 0.9 & 35 & 0.1 & 32.5 & 1.3 \\
Se $(\mathrm{mg} / \mathrm{kg})$, LV & 0.7 & 0.4 & 0.1 & 11 & 0.2 & 1.4 & 0.6 \\
$\mathrm{Se}(\mathrm{mg} / \mathrm{kg})$, East & 4.5 & 7.3 & 1.7 & 18 & 0.3 & 32.5 & 2.4 \\
$\mathrm{Se}(\mathrm{mg} / \mathrm{kg})$, West & 1.9 & 1.8 & 0.7 & 6 & 0.1 & 4.2 & 0.9 \\
\hline
\end{tabular}

\section{Loggerhead Shrike Feather Sample Results, 2004}

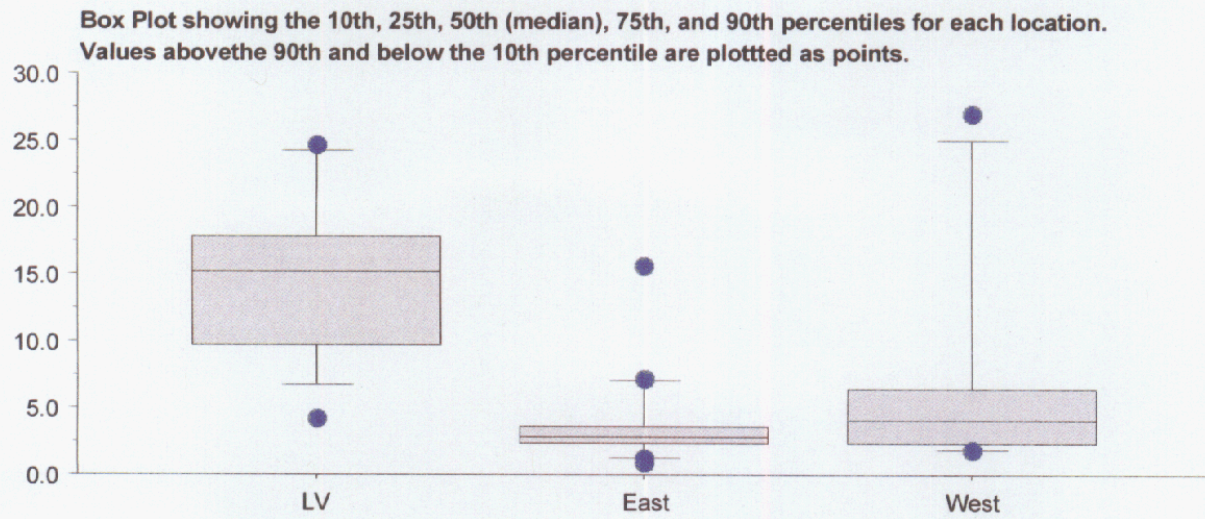

Descriptive Statistics split by location.

\begin{tabular}{lrrrrrrr} 
& Mean & Std. Dev. & Std. Error & Count & Minimum & Maximum & Geom. Mean \\
\hline Se $(\mathrm{mg} / \mathrm{kg})$, Total & 8.1 & 7.5 & 1.3 & 33 & 0.9 & 27.0 & 5.4 \\
Se $(\mathrm{mg} / \mathrm{kg})$, LV & 14.7 & 6.3 & 1.9 & 11 & 4.2 & 24.7 & 13.2 \\
Se $(\mathrm{mg} / \mathrm{kg})$, East & 3.8 & 3.5 & 0.9 & 16 & 0.9 & 15.7 & 3.0 \\
Se $(\mathrm{mg} / \mathrm{kg})$, West & 7.6 & 9.7 & 3.9 & 6 & 1.8 & 27.0 & 4.8 \\
\hline
\end{tabular}

Figure 7. East area loggerhead shrikes blood selenium levels were significantly elevated $(p<0.01)$ compared to control site shrikes and west area shrikes were intermediate. East area shrikes were slightly above the Most Tolerant Dietary Level (MTDL of $2 \mathrm{mg} \mathrm{Se} / \mathrm{kg}$ ). Feather concentrations from east and west area loggerhead shrikes were significantly lower $(\mathrm{p}<0.02)$ than control shrikes. 


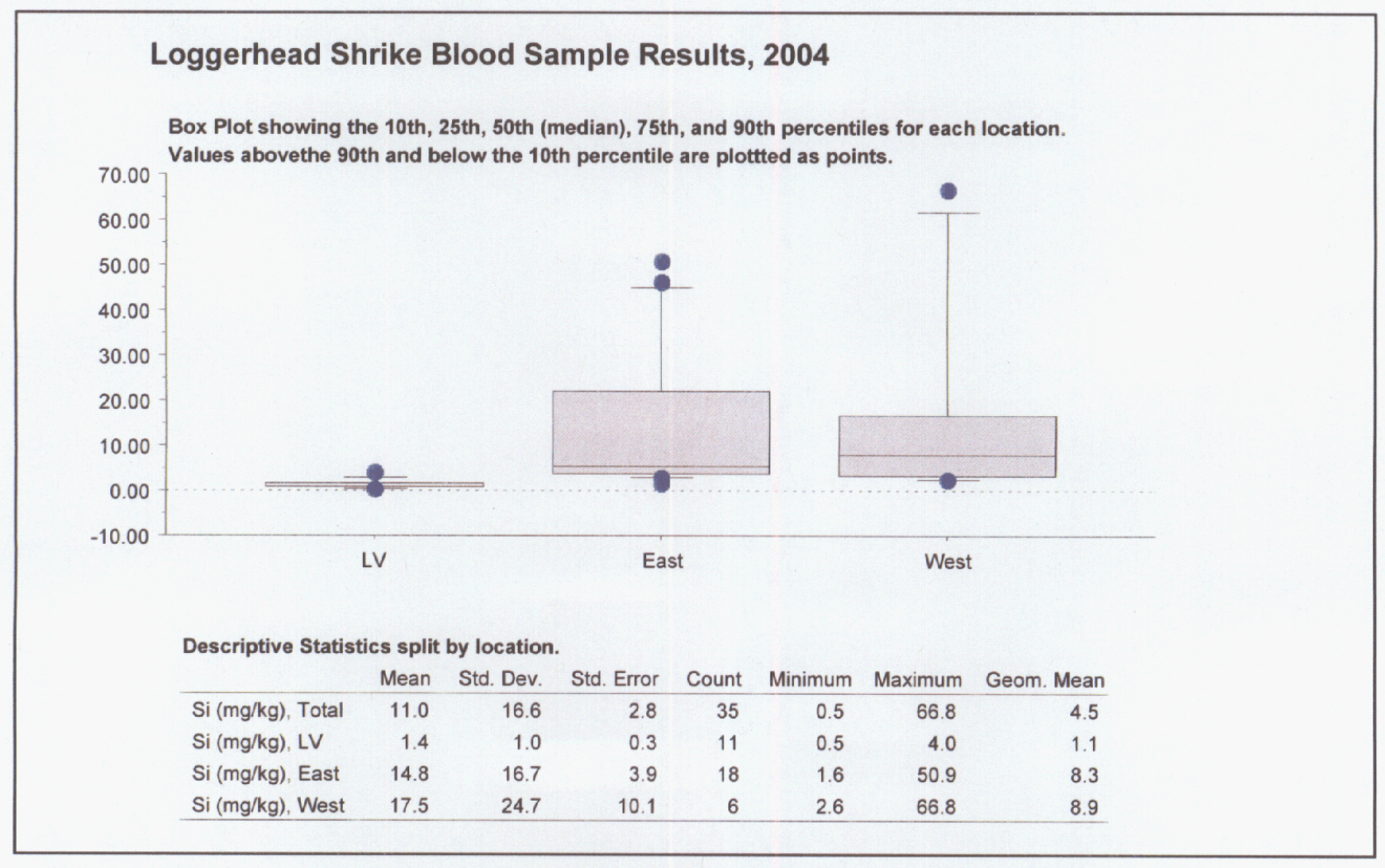

\section{Loggerhead Shrike Feather Sample Results, 2004}

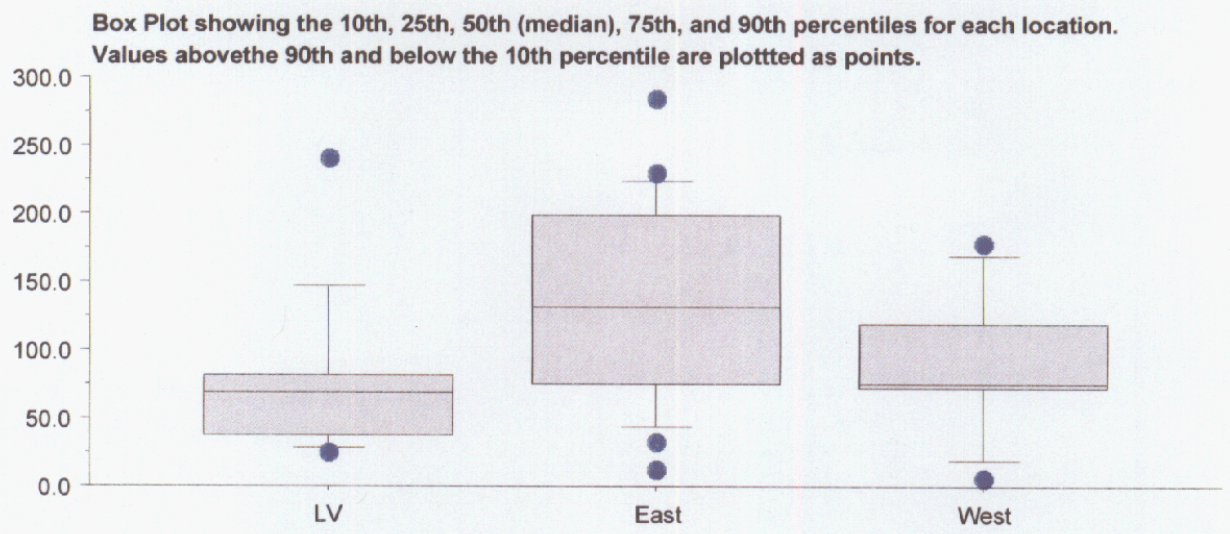

Descriptive Statistics split by location.

\begin{tabular}{lrrrrrrr} 
& Mean & Std. Dev. & Std. Error & Count & Minimum & Maximum & Geom. Mean \\
\hline Si $(\mathrm{mg} / \mathrm{kg})$, Total & 109.8 & 71.2 & 11.9 & 36 & 6.1 & 283.7 & 84.3 \\
Si $(\mathrm{mg} / \mathrm{kg})$, LV & 75.3 & 59.3 & 17.9 & 11 & 24.5 & 241.0 & 61.7 \\
Si $(\mathrm{mg} / \mathrm{kg})$, East & 139.1 & 74.1 & 17.5 & 18 & 12.4 & 283.7 & 113.0 \\
Si $(\mathrm{mg} / \mathrm{kg})$, West & 88.8 & 53.6 & 20.3 & 7 & 6.1 & 178.8 & 65.0
\end{tabular}

Figure 8. Blood silicon concentrations were significantly higher $(p<0.01)$ in Site 300 loggerhead shrikes compared to control shrikes. Most Tolerant Dietary Level (MTDL) data is not available for silicon; feather silicon levels were similar among sites. 


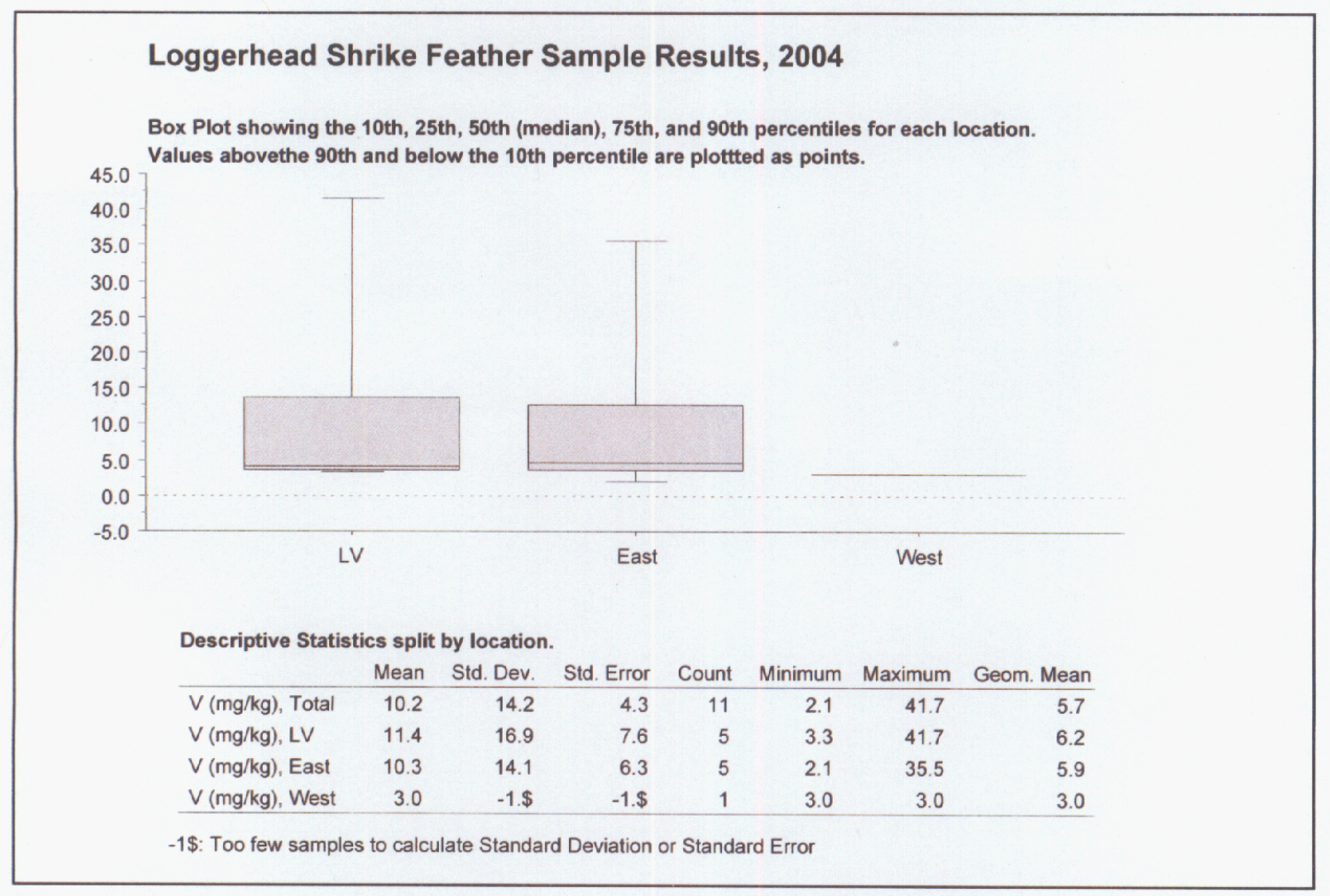

Figure 9. Vanadium was not detected in blood samples from either study area. Vanadium levels in feathers were similar between east area birds and control shrikes. Information on vanadium in feathers of birds from other studies is lacking. 